\title{
Glutamate dehydrogenase of the germinating triticale seeds: gene expression, activity distribution and kinetic characteristics
}

\author{
Agnieszka Grabowska • Marcin Nowicki • \\ Joanna Kwinta
}

Received: 28 December 2010/Revised: 20 April 2011/Accepted: 10 June 2011/Published online: 25 June 2011

(C) The Author(s) 2011. This article is published with open access at Springerlink.com

\begin{abstract}
On the cross-roads of main carbon and nitrogen metabolic pathways, glutamate dehydrogenase (GDH, E.C. 1.4.1.2) carries out the reaction of reductive amination of 2-oxoglutarate to glutamate (the anabolic activity; $\mathrm{NAD}(\mathrm{P}) \mathrm{H}-\mathrm{GDH})$, and the reverse reaction of oxidative deamination of glutamic acid (the catabolic activity; $\left.\mathrm{NAD}(\mathrm{P})^{+}-\mathrm{GDH}\right)$. To date, there have been no reports on identification of $G D H$ genes in cereals. Here, we report cloning and biochemical characterization of the GDH from germinating triticale seeds, a common Polish cereal. A single $T s G D H 1$ gene is $1,620 \mathrm{bp}$ long, while its $1,236 \mathrm{bp}$ long open reading frame encodes a protein of 411 amino acids of high homology with the published GDH protein sequences from other plants. Phylogenetic analyses locate the TsGDH1 among other monocotyledonous proteins and among the sequences of the $\beta$-type subunit of plant GDHs. Changes in TsGDH1 expression and the dynamics of enzyme activity in germinating seeds confirm the existence of one TsGDH isoform with varying expression and activity patterns, depending on the tissue localization and stage of germination. The four-step purification method
\end{abstract}

Communicated by S. Weidner.

A. Grabowska and M. Nowicki contributed equally to the published work.

A. Grabowska ( $\square) \cdot$ J. Kwinta

Department of Biochemistry, Faculty of Agriculture

and Biology, Warsaw University of Life Science,

159 Nowoursynowska St, 02-776 Warsaw, Poland

e-mail: agnieszka_grabowska@sggw.pl

M. Nowicki

Department of Genetics, Breeding, and Biotechnology,

Research Institute of Vegetable Crops, 1/3 Konstytucji

3 Maja St, 96-100 Skierniewice, Poland (including the anionite chromatography using HPLC) resulted in a protein preparation with a high-specific activity and purification factor of approx. 230. The purified enzyme exhibited an absolute specificity towards 2-oxoglutarate $(\mathrm{NAD}(\mathrm{P}) \mathrm{H}-\mathrm{GDH})$, or towards L-glutamate in the reverse reaction $\left(\mathrm{NAD}(\mathrm{P})^{+}-\mathrm{GDH}\right)$, while its low $K_{\mathrm{m}}$ constants towards all substrates and co-enzymes may suggest its aminating activity during germination, or, alternatively, its capability to adjust the direction of the catalyzed reaction according to the metabolic necessity.

Keywords Glutamate dehydrogenase gene . Enzyme purification · Gene expression . Germinating seeds $\cdot$ Triticale

$\begin{array}{ll}\text { Abbreviations } \\ \text { PCR } & \text { Polymerase chain reaction } \\ \text { NAD } & \text { Nicotinamide adenine dinucleotide } \\ \text { NADH } & \text { Reduced form NAD }{ }^{+} \\ \text {NADPH } & \begin{array}{l}\text { Reduced form nicotinamide adenine } \\ \text { dinucleotide phosphate }\end{array} \\ \text { DEAE } & \begin{array}{l}\text { Diethyl-aminoethyl- } \\ \text { HPLC }\end{array} \\ \text { High-pressure liquid chromatography }\end{array}$

Introduction

Acquisition and assimilation of nitrogen and $\mathrm{CO}_{2}$ constitute two fundamental metabolic processes; on which, the plant growth and development depend on. Hence, it is of utmost importance that plants maintain a balance between the pools of carbon and nitrogen metabolites at each developmental stage, from the germinating seed to the 
full-grown plant. Glutamate dehydrogenase (GDH; E.C. 1.4.1.2) is an enzyme that links both of those metabolic pools within a cell, as it can carry out the reaction of reductive amination of 2-oxoglutarate to glutamate (the anabolic activity; NADH-GDH), and the reverse reaction of oxidative deamination of glutamic acid (the catabolic activity; $\left.\mathrm{NAD}^{+}-\mathrm{GDH}\right)$. Changes in the NADH-GDH to $\mathrm{NAD}^{+}-\mathrm{GDH}$ ratio are often used in studies of plant metabolism to assign a function to the enzyme (Loulakakis and Roubelakis-Angelakis 1991, 1992). The native GDH proteins consist of two subunit types: $\alpha$ (molecular mass of $42.5 \mathrm{kDa}$ ) and $\beta$ (molecular mass of $43.0 \mathrm{kDa}$ ) which, combined in different ratios into a hexamer, form varying GDH isoenzymes. If majority of the subunits building one hexamer is of the $\alpha$-type, the enzyme molecule catalyzes the 2-oxoglutarate amination reaction; and reversely, domination of the $\beta$-type subunits makes the enzyme carry out the glutamate deamination (Loulakakis and Roubelakis-Angelakis 1996; Purnell et al. 2005; Turano et al. 1997). Recently, there have been many molecular and genetic analyses aimed at the elucidation of physiological function and the regulatory mechanisms of GDH. Transgenic studies and quantitative genetic approach suggest that the reaction catalyzed by GDH is important in the control of plant growth and productivity (Dubois et al. 2003). So far, $G D H$ genes have been obtained and sequenced in eight plant species. Phylogenetic analyses demonstrated that plant GDH is encoded by a small gene family represented by three genes that have been hitherto described, each coding for distinct GDH subunits (Lehman and Ratajczak 2008). There are two genes conferring the synthesis of both types of GDH subunits in Arabidopsis, vine and tobacco plants (Loulakakis and RoubelakisAngelakis 1996; Purnell et al. 1997; Restivo 2004; Sakakibara et al. 1995; Turano et al. 1997). Only one gene coding for the GDH has been cloned from tomato, while the existence of two subunit types has been explained by its posttranscriptional modifications (Purnell et al. 1997). Among the monocotyledonous plants, up to now the GDHencoding genes have been cloned from rice and maize (Qiu et al. 2009; Sakakibara et al. 1995); however, there have been no full-length GDH-encoding sequences available for other important cereals, such as wheat, barley, rye or triticale. To increase the knowledge on the GDH genes in monocotyledonous plants, we described not only the enzyme's nucleotide sequence, but also its expression level in different tissues and organs (scutellum, endosperm, roots, etc.) both during germination and post-germinative growth of the triticale plant. For this purpose, we have isolated a gene of $x$ Triticosecale (TsGDH1, Gene Bank Accession Number: HQ658905). Thus, obtained sequence may be of use when cloning gene(s) from related species, i.e. wheat or rye.
Despite numerous investigations carried out with sophisticated techniques and methods, both the direction of the reaction catalyzed in vivo by GDH, and the physiological functions of its multiple isoforms in plants remain to be fully clarified. It is possible that the very existence of many enzyme isoforms specific for various tissues and different developmental stages make the data interpretation difficult. It can thus be presupposed that one can satisfactorily explain the metabolic role of this enzyme in plants only after having analyzed the genetic and molecular data from all ontogenetic stages of many plants (Dubois et al. 2003; Masclaux-Daubresse et al. 2006; Purnell and Botella 2007; Skopelitis et al. 2007).

As yet, no such complex analyses have been carried out with regard to GDH in cereals, including triticale. For that reason, the authors aimed at identifying the triticale GDH gene and determining its expression profile during seed germination. In addition, the GDH activity dynamics and distribution at this developmental stage have been studied. The results obtained prompted us to partially purify the GDH isolated from the scutellum of the germinating seeds and characterize it biochemically.

\section{Materials and methods}

Plant material and growth conditions

Dry and germinating seeds of triticale $x$ Triticosecale Wittm. cv. Witon were used for the analyses. The seeds, surface-sterilized with $5 \%$ hypochlorite, were germinated in darkness at $22^{\circ} \mathrm{C}$ and $100 \%$ relative humidity. Samples were taken after $8,16,24,48$, and $72 \mathrm{~h}$ of germination. The samples were immediately frozen in liquid nitrogen and stored at $-80^{\circ} \mathrm{C}$ until use.

\section{Cloning procedures}

Total RNA was extracted from scutellum and endosperms of seeds imbibed for $8,16,24 \mathrm{~h}$ and from scutellum, endosperm, shoots and roots coming from the seeds imbibed for 48 and $72 \mathrm{~h}$. RNA was isolated using a standard guanidinium thiocyanate/acidic phenol extraction method (Chomczynski and Sacchi 1987). RNA concentration and purity were determined spectrophotometrically by absorption at 260, 230 and $280 \mathrm{~nm}$. The integrity of isolated RNA was analyzed on $1.5 \%(\mathrm{w} / \mathrm{v})$ agarose/formaldehyde gel. Aliquots of RNA were treated with $2 \mathrm{U}$ per $1 \mu \mathrm{g}$ RNA of RNase-free DNase I (Fermentas) to remove template DNA. First-strand cDNAs were produced with $1 \mu \mathrm{g}$ of total RNA $\left(72 \mathrm{~h}\right.$ roots) primed with an oligo $(\mathrm{dT})_{12-18}$ primer, with avian myeloblastosis virus reverse transcriptase (AMV RT) following the manufacturer's protocol (Promega). 
Two pair of degenerate primers: TG1-F $5^{\prime}$ GTNTTYAC NCARAARATHCAYG 3'; TG1-R $5^{\prime}$ CATRTCNGGN GCNGGNACRTC $3^{\prime}$ (product length $429 \mathrm{bp}$ ) and TG2-F 5' ATGAAYGCNYTNGCNGCNAC 3'; TG2-R 5' CATRA ANCCYTGDATRTTYTG $3^{\prime}$ (product length $702 \mathrm{bp}$ ) were used to amplify cDNA fragments of the $T s G D H$. Degenerate primers were derived from the conserved regions of $\mathrm{GDH}$ homologous sequences of Oryza sativa (Acc. $\mathrm{Nr}$. BAE48298), Zea mays (Acc. Nr. NP_001105301), Nicotiana tabacum (Acc. Nr. CAD12373), Solanum lycopersicum (Acc. Nr. AF403178_1). PCR reactions were performed in a PTC-200 Peltier Thermal Cycler (MJ Research) under the following conditions: $2 \mathrm{~min}$ at $94^{\circ} \mathrm{C}, 35$ cycles of $30 \mathrm{~s}$ at $94^{\circ} \mathrm{C}, 30 \mathrm{~s}$ at $55^{\circ} \mathrm{C}, 1 \mathrm{~min}$ at $72^{\circ} \mathrm{C}$, and a final extension step for $7 \mathrm{~min}$. PCR was performed using a $50 \mu \mathrm{l}$ reaction mixture that contained $1 \mu \mathrm{lDNA}$ (72 h roots), $0.2 \mathrm{mM}$ each of dNTP, $500 \mathrm{nM}$ of each primer, $1 \times$ Green GoTaq $^{\circledR}$ Flexi Buffer, $5 \mathrm{mM} \mathrm{MgCl}_{2}$ and $1.25 \mathrm{U}$ of GoTaq ${ }^{\circledR}$ Flexi DNA Polymerase (Promega). The resulting amplified fragment was cloned to pGEM-T Easy (Promega) and sequenced.

The full-length cDNA was obtained using GeneRacer Kit (Invitrogen). The RACE-ready first-strand cDNA used as a template for $5^{\prime}$ RACE and $3^{\prime}$ RACE was prepared from total RNA isolated from $72 \mathrm{~h}$ roots with the random primers or GeneRacer OligodT Primer, respectively, according to the manufacturer's instructions. First-strand synthesis was performed with SuperScript III Reverse Transcriptase (Invitrogen), according to the manufacturer's instructions. The gene-specific primers used for RACE were designed from the above partial $T s G D H$ cDNA sequence. The primer rGDH-R1 (5' CAACGCACAGACAA TGGCATGGATA $3^{\prime}$ ) was used for $5^{\prime}$ RACE, and rGDH-F1 (5' CAACGCACAGACAATGGCATGGATA $3^{\prime}$ ) was used for $3^{\prime}$ RACE. PCR reactions were performed under the following conditions: $2 \mathrm{~min}$ at $94^{\circ} \mathrm{C}, 35$ cycles of $30 \mathrm{~s}$ at $94^{\circ} \mathrm{C}, 30 \mathrm{~s}$ at $58^{\circ} \mathrm{C}, 1 \mathrm{~min}$ at $68^{\circ} \mathrm{C}$, and a final $10 \mathrm{~min}$ at $68^{\circ} \mathrm{C}$. PCR was performed using a $50 \mu \mathrm{l}$ reaction mixture that contained $1 \mu \mathrm{lDNA}, 0.2 \mathrm{mM}$ each of dNTP, $500 \mathrm{nM}$ of each primer, $1 \times$ high fidelity PCR buffer, $5 \mathrm{mM} \mathrm{MgCl}$ and $2.5 \mathrm{U}$ of Platinum ${ }^{\circledR}$ Taq DNA Polymerase (Invitrogen). The resulting amplified fragment was cloned to TOPO TA Cloning Kit (Invitrogen) and sequenced. Sequencing was performed with the ABI Prism BigDye Terminator Cycle Sequencing Kit on the ABI Prism 3730 DNA analyzer (Applied Biosystems). Trace files were checked and edited using Chromas 1.55 (Technelysium, USA). Sequences were verified by database searching at the National Center for Biotechnology Information server using BLAST algorithm (http://www.ncbi.nlm.nih.gov). Sequence date from this article has been deposited at GenBank. The deduction of the amino acid sequence, calculation of the theoretical molecular mass and $p I$ was performed with ExPASy (http://www.expasy.ch/tools/). Multiple alignments of GDH amino acids sequences and a phylogenetic neighbor-joining tree were generated by the program CLUSTAL W (Thompson et al. 1994).

Expression analysis by semi-quantitative RT-PCR

Total RNA samples were used from scutellum and endosperms of seeds imbibed for 8, 16, $24 \mathrm{~h}$ and from scutellum, endosperm, shoots and roots of seeds imbibed for 48 and $72 \mathrm{~h}$ were used. Semi-quantitative RT-PCR analysis was performed using One-Step RT-PCR Kit (Novagen) according to the manufacturer's instructions. Optimal numbers of PCR cycles within the linear range of amplifications were determined for primer pair. Aliquots of total RNA (100 ng) were used as templates in One-Step RT-PCR with the forward primer eGDH-F 5' TATGT TGGGTTTAGGGTGCAGC $3^{\prime}$ and reverse eGDH-R $5^{\prime}$ GCAGCCCAGGAGCCAACATTAC $3^{\prime}$ (product length $515 \mathrm{bp}$ ). The RT-PCR reaction for the plant $18 S \mathrm{rRNA}$ genes using specific primers rRNA-F $5^{\prime}$ CCAGGTCCAGA CATAGTAAG $3^{\prime}$ and rRNA-R 5' GTACAAAGGGCAGG GACGTA 3' (product length $427 \mathrm{bp}$ ) was also performed as a control. RT-PCR reactions were carried out under the following conditions: $30 \mathrm{~min}$ at $50^{\circ} \mathrm{C}, 2 \mathrm{~min} 94^{\circ} \mathrm{C}, 32$ (for $T s G D H$ ) or 10 cycles (for rRNA) of $30 \mathrm{~s}$ at $94^{\circ} \mathrm{C}, 45 \mathrm{~s}$ at $60^{\circ} \mathrm{C}$ and final extension step for $5 \mathrm{~min}$ at $68^{\circ} \mathrm{C}$. Densitometry was conducted with the program ImageJ version 1.44 (http://www.rsb.info.nih.gov/ij).

Enzyme activity and protein analysis

TsGDH1 were extracted from scutellum and endosperms of seeds imbibed for 8, 16, $24 \mathrm{~h}$ and from scutellum, endosperm, shoots and roots of seeds imbibed for 48 and $72 \mathrm{~h}$. Procedure of the enzyme isolation from the triticale seedlings was described earlier (Kwinta et al. 2001). GDH activity was determined in both the aminating and the deaminating directions by following the absorption change at $340 \mathrm{~nm}$ (Barash et al. 1973). Specific activity of GDH was expressed as the reduction or oxidation of $1.0 \mu \mathrm{mol}$ coenzyme $\left(\mathrm{NAD}^{+}\right.$or NADH respectively) per mg protein per minute at $30^{\circ} \mathrm{C}$. Protein concentration was determined colorimetrically according to the Bradford method (1976) using bovine serum albumin as a standard.

Native polyacrylamide gel electrophoresis (PAGE) of GDH extracts was performed by modified Laemmli method (1970) on $7.5 \%$ resolving and 4\% stacking gel. Bands with GDH activity were visualized on the gel using the tetrazolium system (Lehman et al. 1990). The GDH protein was isolated and purified from the scutellum of the seeds subjected to $48 \mathrm{~h}$ of germination. The procedure published elsewhere (Kwinta et al. 2001) has been employed, with 
one modification: after salt-based precipitation, the samples have been separated by means of HPLC in the Waters Multisolvent Delivery System apparatus. The protein has been partially purified in four steps, including heating the protein suspension at $50^{\circ} \mathrm{C}$, ammonium sulfate-derived precipitation (the enzyme was recovered from the fraction between 30 and $60 \%$ of the sample saturation) and ionexchange chromatography (anionite) on the 15HR DEAE $(1 \times 10 \mathrm{~cm})$ column (Waters). The whole purification procedure, with exception of the heat $\left(50^{\circ} \mathrm{C}\right)$ precipitation of the thermolabile proteins, has been carried out at $4^{\circ} \mathrm{C}$. After each purification step, the NAD(P)H-GDH activity and protein concentration have been determined. The enzyme activity and protein concentration have been determined at each purification stage. GDH activity has been expressed as total activity (IU, i.e. $\mu$ mol of oxidized/ reduced co-enzyme per minute) or specific activity (IU per $\mathrm{mg}$ of protein).

The kinetic constant values $\left(K_{\mathrm{m}}\right)$ for each substrate were calculated using the method of Lineweaver and Burk (1934). The substrate concentrations used were in the range from 1.5 to $30 \mathrm{mM}$ for 2-oxoglutarate, $\mathrm{NH}_{4} \mathrm{Cl}$ and L-glutamate and also from 0.003 to $0.125 \mathrm{mM}$ for coenzymes $\mathrm{NAD}^{+}, \mathrm{NADH}, \mathrm{NADPH}$.

\section{Statistical analysis}

For the measurement of enzyme activities and kinetic constant values, the results are presented as mean $\pm \mathrm{SD}$ (standard deviation) for three independent experiments, each with two replications. Standard deviation was up to $7 \%$ of the corresponding mean value in all cases. The statistical significance of differences was determined by Student's test at $P<0.05$ (MS Excel).

\section{Results and discussion}

\section{Cloning and characterization of the $T s G D H 1$ cDNA clones}

Based on the RT-PCR strategy $T s G D H 1$ gene was isolated and designated as $x$ Triticosecale glutamate dehydrogenase 1 (Gene Bank Accession Number: HQ658905). First, two pairs of the degenerate primers were designed based on the conserved region of the four known sequences of the plant glutamate dehydrogenases. The primers were subsequently used to amplify a 429 and 702 bp products, respectively. Two additional primers were designed based on the confirmed sequences and used for the isolation of the $5^{\prime}$ - and $3^{\prime}$-ends of the EST.

The full-length of the TsGDHI is $1,620 \mathrm{bp}$ long and contains a 1,236 bp long open reading frame (ORF), a $5^{\prime}$ untranslated region $\left(5^{\prime}\right.$-UTR) of $125 \mathrm{bp}$ and $3^{\prime}$ UTR of 259 bp (Fig. 1). The ORF of the TsGDHI encodes a protein of 411 amino acids with a calculated molecular mass of $44.2 \mathrm{kDa}$ and an isoelectric point of 6.19 .

Overall sequence alignment analysis revealed that the TsGDH1 is highly homologous to GDHs from other plants, both at the nucleotide and the deduced amino acid levels. The protein coded by the $T_{s} G D H 1$ showed greatest similarity (as estimated with the Blastp program) to the glutamate dehydrogenase family proteins of: Oryza sativa (BAE48296, 96\% similarity within a 411 amino acid overlap, max score 826), Zea mays (AAB51595, 94\% similarity within a 411 amino acid overlap, max score 805), Asparagus officinalis (CAA09478, 89\% similarity within a 411 amino acid overlap, max score 775), Solanum lycopersicum (AAL36888, 86\% similarity within a 411 amino acid overlap, $\max$ score 748), Arabidopsis thaliana (NP_187041, 84\% similarity within a 411 amino acid overlap, max score 741) (Fig. 2).

Several reports have demonstrated that the plant GDHs are encoded by at least two genes, each coding for an $\alpha$ - or

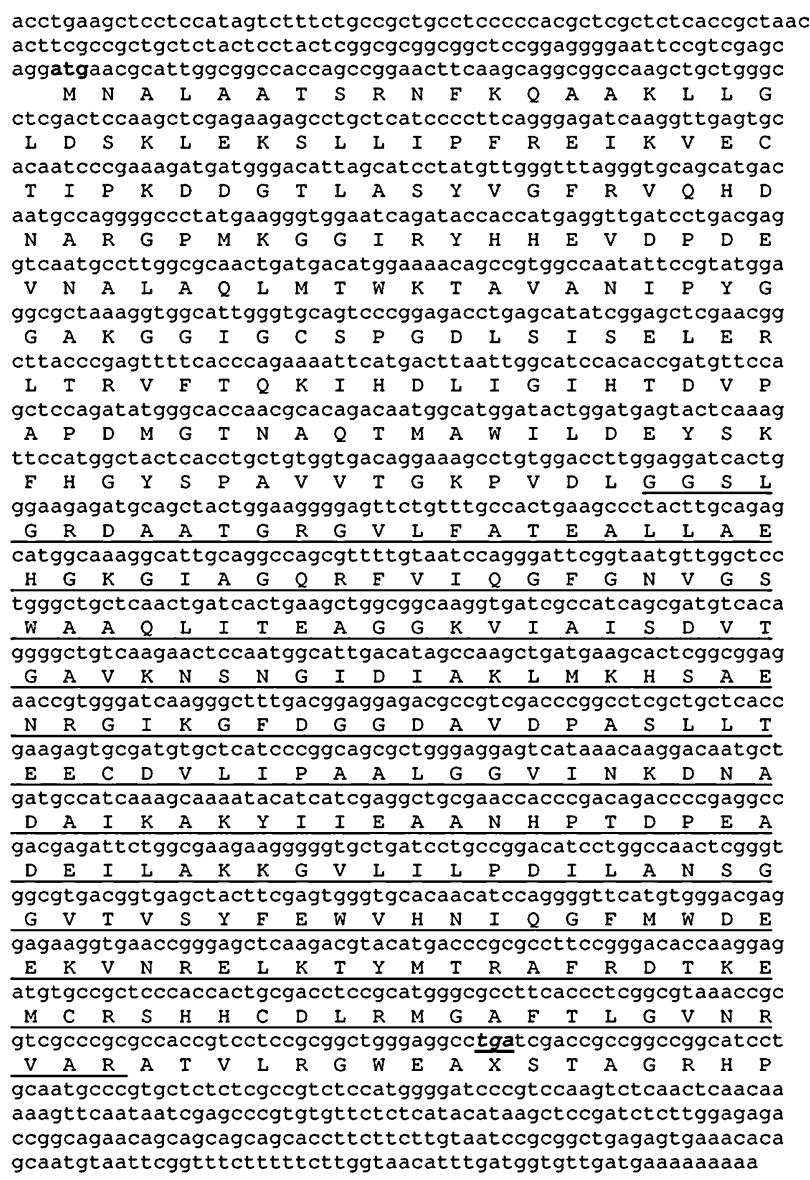

Fig. 1 Nucleotide and putative amino acid sequences of TsGDH1. The start codon (ATG) was bolded and stop codon (TGA) was bolded, italicized underlined. The $\mathrm{NAD}(\mathrm{P})$ binding domain of glutamate dehydrogenase was underlined 
$\beta$-subunit, respectively, randomly associating to give rise to the various hexameric isoenzymes (Loulakakis and Roubelakis-Angelakis 1991; Melo-Oliveira et al. 1996; Miyashita and Good 2008; Purnell et al. 2005). To investigate what subunit type the cloned $T s G D H 1$ gene is coding for, and to reveal the evolutionary relationship between the TsGDH1 and GDHs from other plants, a phylogenetic tree was constructed based on the deduced amino acids sequences of the GDH genes. The following sequences have been used: monocots GDH are represented by Oryza sativa (AAQ01156 - $\beta$ subunit), Zea mays (BAA08445- $\beta$ subunit), Asparagus officinalis (CAA09478- $\beta$ subunit), while the dicots GDH are represented by Arabidopsis thaliana (NP_197318 — $\beta$ subunit and AAB01222— $\alpha$ subunit), Vitis vinifera (CAA605007— $\alpha$ subunit), Nicotiana plumbaginifolia (CAA69601 - $\beta$ subunit and CAA69600$\alpha$ subunit). The phylogenetic tree analysis clearly distinguishes two groups of sequences encoding either the $\alpha$ - or $\beta$-subunit of the GDH holoenzyme (Fig. 3). The tree comprised of two major branches, each of them containing monocotyledonous and dicotyledonous plant-derived sequences. This suggests that the sequences grouped according to the nature of the subunit encoded $(\alpha-$ or $\beta$ ), rather than according to the species of origin. In addition, the phylogenetic analyses demonstrated that the TsGDH1 of $x$ Triticosecale belongs to the branch occupied by another monocotyledonous species, but most importantly, it has been placed among the sequences encoding the $\beta$-type subunit of plant GDH.

Activity distribution and the $T s G D H 1$ expression pattern in the germinating seeds

During seed germination, the storage protein degradation to oligopeptydes and free amino acids takes place (Glevarec et al. 2004). The glutamic acid freed in such a manner may
Fig. 2 An alignment (ClustalW) of the deduced amino acid sequence of TsGDH1 cDNA with other homologous sequences: Oryza sativa (BAE48296), Zea mays (AAB51596), Asparagus officinalis (CAA09478), Solanum lycopersicum (AAL36888), Arabidopsis thaliana (NP_187041). Identical, conserved and semiconserved residues in all aligned sequences are indicated by asterisks $(*)$, colons $(:)$, and dots (.), respectively

O.sativa
TsGDH1
Z.mays
A.officinalis
A.thaliana

O.sativa
TsGDH1
Z.mays
A.officinalis
A.thaliana

O.sativa
TsGDH1
Z.mays
A.officinalis
A.thaliana
O.sativa
TsGDH1
Z.mays
A.officinalis
A.thaliana

MNALAATSRNFKQAAKLLGLDSKLEKSLLIPFREIKVECTIPKDDGTLASYVGFRVQHDN MNALAATSRNFKOAAKLLGLDSKLEKSLLIPFREIKVECTIPKDDGTLASYVGFRVQHDN MNALAATSRNFKOAAKLVGLDSKLEKSLLIPFREIKVECTIPKDDGTLASYVGFRVOHDN MNALAATSRNFKQAAKLLGLDPKLEKSLLIPFREIKVECTIPKDDGTLASFVGFRVQHDN MNALAATNRNFKLASRLLGLDSKLEKSLLIPFREIKVECTIPKDDGTLASFVGFRVQHDN

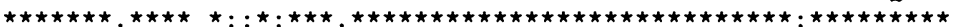

ARGPMKGGIRYHHEVDPDEVNALAOLMTWKTAVANIPYGGAKGGIGCSPGDLSISELERL ARGPMKGGIRYHHEVDPDEVNALAQLMTWKTAVANIPYGGAKGGIGCSPGDLSISELERL ARGPMKGGIRYHHEVDPDEVNALAQLMTWKTAVANIPYGGAKGGIGCSPGDLSISELERL ARGPMKGGIRYHSEVDPDEVNALAQLMTWKTAVANIPYGGAKGGIGCSPGDLSLSELERL ARGPMKGGIRYHPEVEPDEVNALAQLMTWKTAVAKIPYGGAKGGIGCDPSELSLSELERL

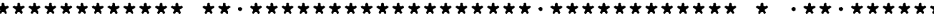

TRVFTQKIHDLIGIHTDVPAPDMGTNSQTMAWILDEYSKFHGYSPAVVTGKPVDLGGSLG TRVFTOKIHDLIGIHTDVPAPDMGTNAOTMAWILDEYSKFHGYSPAVVTGKPVDLGGSLG TRVFTQKIHDL IGIHTDVPAPDMGTNSQTMAWILDEYSKFHGYSPAVVTGKPVDLGGSLG TRVFTOKIHDLIGVHTDVPAPDMGTNAOTMAWILDEYSKFHGYSPAIVTGKPVDLGGSLG TRVFTQKIHDL IGIHTDVPAPDMGTGPQTMAWILDEYSKFHGHSPAVVTGKP IDLGGSLG

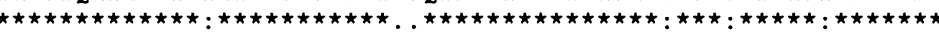

RDAATGRGVLFATEALLAEHGKGIAGQRFVIQGFGNVGSWAAQLISEAGGKVIAISDVTG RDAATGRGVLFATEALLAEHGKGIAGORFVIOGFGNVGSWAAOLITEAGGKVIAISDVTG RDAATGRGVIFATEALLAEHGKGIAGQRFVIQGFGNVGSWAAQLISEAGGKVIAISDVTG RDAATGRGVLFATEALLAEYGKGISGQRFVIQGFGNVGSWAAQLITKAGGKVVAVSDVTG RDAATGRGVLFATEALLNEHGKTISGQRFAIQGFGNVGSWAAKLISDKGGKIVAVSDVTG

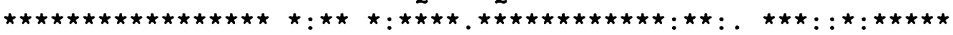

AVKNSNGLDIAKLMKHSSENRGIKGFDGGDAIDPRSLLTEECDVLIPAALGGVINKDNAN AVKNSNGIDIAKLMKHSAENRGIKGF DGGDAVDPASLLTEECDVLIPAALGGVINKDNAD AVKNVDGLDIAQLVKHSAENKGIKGFKGGDAIAPDSLLTEECDVL IPAALGGVINKDNAN AIKHSNGLDIENLLKYSVKNRGIKGF SGGDAIDSNSLLTEDCDVLIPAALGGVINRENAN AIKNNNGIDILSLLEHAEENRGIKGFDGADSIDPDSILVEDCDILVPAALGGVINRENAN

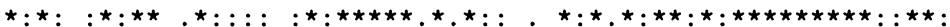

EIKAKYIIEAANHP TDPEADEILSKKGVLILPDILANSGGVTVSYFEWVQNIQGFMWDEE AIKAKY IIEAANHP TDPEADEILAKKGVLILPDILANSGGVTVSYFEWVHNIQGFMWDEE DIKAKYIIEAANHP TDPEADEILSKKGVLILPDILANSGGVTVSYFEWVQNIQGFMWDEE DVRAKF I IEAANHP TDPEADEILSKKGVCILPDILANSGGVTVSYFEWVQNIQGFMWDEE EIKAKF IIEGANHP TDPEADEILKKKGVMILPDIYANSGGVTVSYFEWVQNIQGFMWDEE

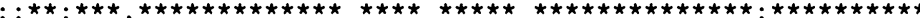

KVNNELKTYMTRGFRDVKEMCRSHHCDLRMGAFTLGVNRVARATVLRGWEA KVNRELKTYMTRAFRDTKEMCRSHHCDLRMGAFTLGVNRVARATVLRGWEA KVNAELRTYMTRAFGDVKQMCRSHSCDLRMGAFTLGVNRVARATVLRGWEA KVNSELKTYMTKGFKHVKEMCKTHNCDLRMGAFTLGVNRVARATLLRGWEA KVNRELKTYMTRGFKDLKEMCQTHSCDLRMGAFTLGINRVAQATTIRGWGS

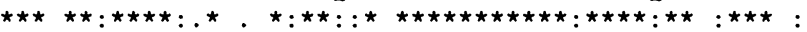




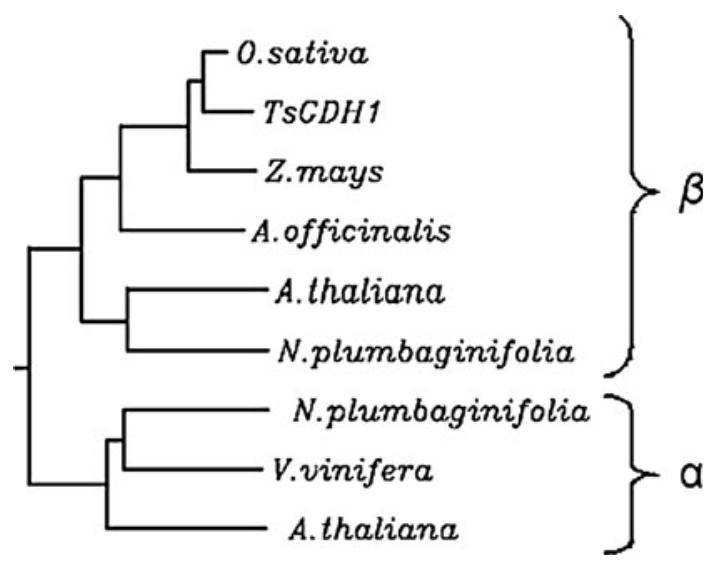

Fig. 3 Phylogenetic tree of TsGDH1 from different plant species. The aligned amino acid sequences were deduced from sequences of GDH derived from genes of the following species: Oryza sativa (AAQ01156), Zea mays (BAA08445), Asparagus officinalis (CAA09478), Arabidopsis thaliana (NP_197318 and AAB01222), Vitis vinifera (CAA605007), Nicotiana plumbaginifolia (CAA69601 and CAA69600)

serve as a substrate to the catabolic GDH activity. Thus, to elucidate the biological functions of the purified TsGDH1, the studies have been undertaken aiming at the analyses of the $T s G D H 1$ expression changes and the dynamics of the activity changes within the germinating seeds of triticale. In addition, an in-depth kinetic characterization of the enzyme isolated for the scutellum germinated for $48 \mathrm{~h}$ was carried out.

The expression of $x$ Triticosecale glutamate dehydrogenase 1 (TsGDHl) gene was investigated using semiquantitative RT-PCR analysis. Total RNA extracted from the scutellum and the endosperms of seeds imbibed for 8 , 16, $24 \mathrm{~h}$ and scutellum, endosperm, shoots and roots of seeds imbibed for 48 and $72 \mathrm{~h}$ were used to investigate the developmental expression profile of the TsGDH1 (Fig. 4). TsGDH I mRNA was detected in all tissues examined, with the highest level (100\% relative density) in scutellum of seeds imbibed for $16 \mathrm{~h}$. The level of TsGDHl was also high in scutellum of seeds imbibed for 8 and $24 \mathrm{~h}$ and roots after 48 and $72 \mathrm{~h}$ germination. Lower transcript level was detected in the scutellum of dry seeds, endosperms of seeds imbibed for 8, 16 and $24 \mathrm{~h}$; scutellum of the seeds imbibed for $48,72 \mathrm{~h}$, and shoots of seeds imbibed for 48 and $72 \mathrm{~h}$. In endosperm of dry seeds and endosperm of seeds imbibed for 48 and $72 \mathrm{~h}$, the TsGDHI transcript level was the lowest. Glevarec et al. (2004) investigated the $G D H$ expression in the embryos and cotyledons of the germinating Medicago truncatula seeds. The GDH gene was essentially expressed in the embryo axis where its transcripts remained at a relatively low and constant level up to $21 \mathrm{~h}$ after imbibition, before a massive increase during the post-germination growth phase. The highest expression level was recorded in the embryo axis of these seeds subjected to $48 \mathrm{~h}$ of germination.

In parallel to the gene expression analyses, the enzymatic activity of TsGDH1 was measured at the same germination stages: the NADH-dependent activity (or the reductive amination of the 2-oxoglutarate), as well as the $\mathrm{NAD}^{+}$dependent activity (the oxidative deamination of the glutamic acid; Table 1) have been investigated. In the endosperm of dried seeds, the enzyme showed the same activity in both directions. At the early stages of the seed germination, i.e. at 8,16 and $24 \mathrm{~h}$ of imbibition, the deaminating GDH activity in the endosperm was predominant, and it was 1.4-, 2.3- and 1.6-fold higher, respectively, than the aminating activity. A shift in the TsGDH1 activity in the seed endosperm was observed after $48 \mathrm{~h}$ of germination: the activity towards glutamate synthesis exceeded 1.3 times activity in the opposite direction (Table 1). These results seem to indicate an involvement of the TsGDH1 in glutamate oxidation at the early stages of seed germination, related to storage protein degradation. Similar results, suggesting GDH involvement in glutamate oxidation during seed germination, were obtained in Phaseolus vulgaris L. (Leon et al. 1990) and Medicago trucatula L. (Glevarec et al. 2004) and Lupinus luteus L. (Lehman and Ratajczak 2008).

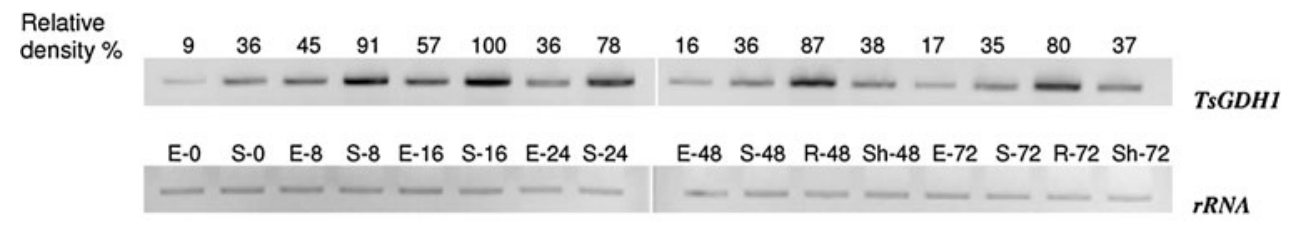

Fig. 4 Expression of $T s G D H 1$ in different compartments of seeds and during different germination stages imbibed for 8, 16, 24, 48 and 72 h. $E-O$ endosperm of dry seeds, $S-O$ scutellum of dry seeds, $E-8$ endosperm of seeds imbibed for $8 \mathrm{~h}, S-8$ scutellum of seeds imbibed for $8 \mathrm{~h}, E-16$ endosperm of seeds imbibed for $16 \mathrm{~h}, S-16$ scutellum of seeds imbibed for $16 \mathrm{~h}, E-24$ endosperm of seeds imbibed for $24 \mathrm{~h}, S$ 24 scutellum of seeds imbibed for $24 \mathrm{~h}, E-48$ endosperm of seeds imbibed for $48 \mathrm{~h}, S-48$ scutellum of seeds imbibed for $24 \mathrm{~h}, R-48$ roots of seeds imbibed for $48 \mathrm{~h}, S h-48$ shoots of seeds imbibed for
$48 \mathrm{~h}, E-72$ endosperm of seeds imbibed for $72 \mathrm{~h}, S-72$ scutellum of seeds imbibed for $72 \mathrm{~h}, R-72$ roots of seeds imbibed for $72 \mathrm{~h}, S h-72$ shoots of seeds imbibed for $72 \mathrm{~h}$. Quantitative one-step RT-PCR analyses were performed with $100 \mathrm{ng}$ of total RNA. Amplification of the 18S rRNA gene was used to ensure that equal amounts of template were added to each RT-PCR. Each figure is representative of one of at least three independent experiments that gave similar results. The relative intensity expression of $T s G D H 1$ was quantified by $\mathrm{NIH}$ Image Software (Version 1.44) 


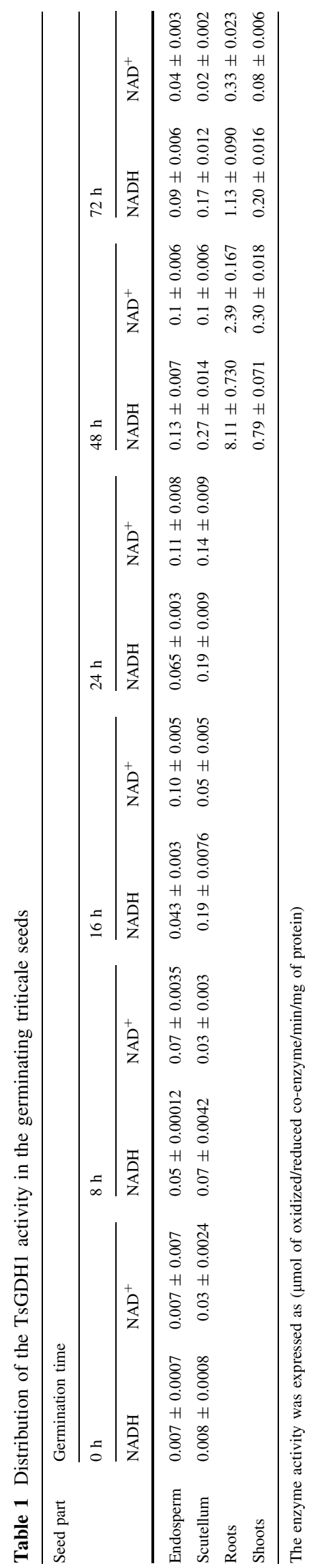

In contrast to the endosperm, in scutellum of the germinating triticale seeds, a gradual increase in the aminating TsGDH1 activity was recorded. The highest NADH-GDH activity level was reached after $48 \mathrm{~h}$ of germination. A very high NADH-GDH activity was measured in roots of seedlings germinating for 48 and $72 \mathrm{~h}$ and it was approx. seven fold higher at $48 \mathrm{~h}$ than at $72 \mathrm{~h}$ of germination. High aminating activity, several-fold higher than deaminating activity, in rapidly growing seedling organs may suggest that TsGDH1 is indeed involved in the reactions leading to glutamic acid synthesis meeting the demands of these organs.

In shoots of seedlings grown for 48 or $72 \mathrm{~h}$, the activity towards glutamate production prevailed as well; however, it was significantly lower than in seedling roots. The shifts in aminating versus deaminating TsGDH1 activity in scutellum, roots and shoots as opposed to endosperm, where the storage compounds prevail, seem to support the hypothesis that the enzyme carries out various functions, depending on its tissue localization and plant developmental stage. It is possible that the enzyme active in the endosperm provides ammonium ion and 2-oxoglutarate, consumed by GDH in scutellum.

Second line of evidence on the dynamics of the TsGDH1 activity changes during the seedling development, in line with the results of the enzymic activity studies, was obtained by means of the gel electrophoretic separation of the isolated protein samples, stained for the GDH activity (Fig. 5). Based on the obtained zymograms, we postulate the existence in all investigated seed parts and at all analyzed germination stages of just one enzyme isoform, characterized by low electrophoretic mobility. Moreover, the intensity of the electrophoretic bands staining indicates the highest TsGDH1 activity in scutellum and roots of the seedling after $48 \mathrm{~h}$ germination and in the roots of the seedlings after $72 \mathrm{~h}$ of germination.

Based on the research carried out over a dozen years, it has been concluded that higher plants synthesize hexameric native proteins of glutamate dehydrogenase, comprising two types of subunits encoded by two distinct genes (Fontaine et al. 2006; Loulakakis and Roubelakis-Angelakis 1991; Purnell et al. 2005; Turano et al. 1997). In contrast to the results obtained for other plant species, we were able to isolate only a single triticale GDH gene. The existence of only one $G D H$ gene, probably encoding a $\beta$-type subunit, corroborates the observation of just one enzyme isoform in triticale. Gene expression studies confirmed changes in GDH activity dynamics and distribution in triticale seeds. Earlier studies analyzing this enzyme in triticale seedlings also indicated the presence of just one isoform, catalyzing a reversible reaction (Kwinta et al. 2001).

The GDH activity determined here in vitro indicates, that both in the endosperm and scutellum of the seeds 


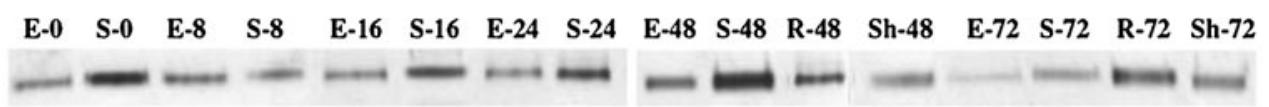

Fig. 5 Electrophoretic image of GDH activity distribution in dry and germinating triticale seeds. $E-O$ endosperm of dry seeds, $S-O$ scutellum of dry seeds, $E-8$ endosperm of seeds imbibed for $8 \mathrm{~h}$, $S-8$ scutellum of seeds imbibed for $8 \mathrm{~h}, E-16$ endosperm of seeds imbibed for $16 \mathrm{~h}, S-16$ scutellum of seeds imbibed for $16 \mathrm{~h}, E-24$ endosperm of seeds imbibed for $24 \mathrm{~h}, S-24$ scutellum of seeds imbibed for $24 \mathrm{~h}, E-48$ endosperm of seeds imbibed for $48 \mathrm{~h}, S-48$

germinated for $48 \mathrm{~h}$, a change in direction of the reaction catalyzed by the enzyme takes place. For that reason, a partial purification and characterization of the GDH isolated from the seed scutellum at this stage of germination have been attempted. Since our earlier research indicated that triticale GDH also accepted NADPH as co-enzyme (Kwinta et al. 2001), at all purification stages both NADHGDH and NADPH-GDH were determined. The employed procedure resulted in obtaining an enzyme concentrate with high specific activity $(51.56 \mu \mathrm{mol}$ of oxidized NADH/ $\mathrm{min} / \mathrm{mg}$ of protein or $8.20 \mu \mathrm{mol}$ of oxidized NADPH/ $\mathrm{min} / \mathrm{mg}$ of protein), and a purification factor of approx. 230 (Table 2).

The purified TsGDH1 has been characterized with regards to its substrate specificity and affinity towards substrates and co-enzymes. To determine the substrate specificity, the GDH activity was measured in presence of its proper substrates (i.e. 2-oxoglutarate or L-glutamic acid), and their analogs (oxaloacetate, L-aspartic acid, and L-glutamine). The enzyme exhibited absolute specificity towards the 2-oxoglutarate as a substrate for the reductive amination reaction, in the presence of the reduced forms of co-enzymes $(\mathrm{NAD}(\mathrm{P}) \mathrm{H})$. The enzyme showed also an absolute specificity to L-glutamate in reverse reaction, taking place in the presence of oxidized forms of the $\left(\mathrm{NAD}(\mathrm{P})^{+}\right)$co-enzymes. Similar property of GDH is described in microorganisms (Consalvi et al. 1991) in triticale roots seedlings (Kwinta et al. 2001) and in soya been seedlings (Turano et al. 1996).

\section{Substrate and co-enzyme affinity}

A preliminary experiment indicated that GDH activities in presence of $\mathrm{NADP}^{+}$were below the assay accuracy. Hence, only NADPH and $\mathrm{NAD}(\mathrm{H})$ were used as coenzymes for this investigation of GDH from triticale (Table 3). The enzyme shows comparable affinity both to the reduced and oxidized form of the co-enzyme, which might point to a certain flexibility of the enzyme when it comes to the direction of the reaction if catalyzed. Moreover, the $K_{\mathrm{m}}$ value for L-glutamate indicates stronger binding of this substrate by GDH, compared with 2-oxoglutarate. scutellum of seeds imbibed for $24 \mathrm{~h}, R-48$ roots of seeds imbibed for $48 \mathrm{~h}, \mathrm{Sh}-48$ shoots of seeds imbibed for $48 \mathrm{~h}, E-72$ endosperm of seeds imbibed for $72 \mathrm{~h}, S-72$ scutellum of seeds imbibed for $72 \mathrm{~h}$, $R-72$ roots of seeds imbibed for $72 \mathrm{~h}, S h-72$ shoots of seeds imbibed for $72 \mathrm{~h}, R-72$ roots of seeds imbibed for $72 \mathrm{~h} .30 \mu \mathrm{g}$ of soluble proteins extracted from the seeds tissues was added per lane. The zymogram is of similar results obtained in three independent experiments

The enzyme isolated from the scutellum of triticale seeds imbibed for $48 \mathrm{~h}$ exhibited high affinity towards substrates and co-enzymes. The investigated enzyme was characterized by low $K_{\mathrm{m}}$ values for each of the coenzymes. Similar properties of the GDH were noted by Hudson and Daniel (1993) in their studies on GDH reaction kinetics. Like it was the case for other plants (Kwinta et al. 2001; Turano et al. 1996) the affinity of the enzyme originating from the germinating seed was higher towards the NADH than the NADPH. A noteworthy feature of the scutellum-isoform of GDH is its high affinity towards ammonium ion (the $K_{\mathrm{m}}$ value is $1.2 \times 10^{-4} \mathrm{M}$ in the presence of NADH, and as much as $4.8 \times 10^{-5} \mathrm{M}$ in the presence of NADPH). Similar kinetic properties were reported for $\mathrm{NADP}(\mathrm{H})-\mathrm{GDH}$ (gdhA) of Aspergillus niger (Abiko et al. 2010). At the same time, in addition to its high affinity to ammonium ion, the scutellum GDH has high affinity to L-glutamic acid as well. It may indicate that during germination, in the triticale seed scutellum, intensive parallel processes of L-glutamic acid catabolism and $\mathrm{NH}_{4}{ }^{+}$-ion assimilation take place. This raises the question for the role GDH plays in triticale seedlings. Our results on the GDH activity in the endosperm of the germinating seeds are in line with the published results (Robinson et al. 1992; Hodges 2002) and constitute an argument for the catabolic function of the enzyme. It is harder to explain the aminating activity of the enzyme recorded in the scutellum of these seeds. Protein degradation, occurring at the early stages of seed germination, leads to a local increase in ammonia concentration, which due to its high toxicity must be neutralized by incorporation into nontoxic metabolites (L-glutamate and L-aspartate being the primary routes for its incorporation in all organisms). Based on the assays with labeled ${ }^{15} \mathrm{NH}_{4}{ }^{+}$, some authors conclude, however, that despite the aminating activity of the enzyme exceeding the deaminating activity in vitro, the GDH was not carrying out the ammonia ion assimilation in vivo (Glevarec et al. 2004). This inconsistence between the in vitro and in vivo activity measurements may suggest an in vivo GDH activity regulation by means of post-translational modifications not existing (or not functioning) in vitro. The GDH activity level and presence (in the endosperm) of an isoform characterized by low electrophoretic mobility the 
Table 2 Purification of the TsGDH1 isolated from the scutellum of the seeds after $48 \mathrm{~h}$ of germination

\begin{tabular}{|c|c|c|c|c|c|c|c|c|c|}
\hline \multirow[t]{2}{*}{ Purification step } & \multicolumn{2}{|c|}{$\begin{array}{l}\text { Total activity }(\mu \mathrm{mol} \text { of } \\
\text { oxid. co-enzyme/min) }\end{array}$} & \multirow[t]{2}{*}{ Protein (mg) } & \multicolumn{2}{|c|}{$\begin{array}{l}\text { Specific activity ( } \mu \mathrm{mol} \text { of } \\
\text { oxid. co-enzyme } / \mathrm{min} / \mathrm{mg} \text { prot.) }\end{array}$} & \multicolumn{2}{|c|}{ Purification factor } & \multicolumn{2}{|c|}{$\begin{array}{l}\text { Purification } \\
\text { efficiency }(\%)\end{array}$} \\
\hline & NADH & NADPH & & NADH & NADPH & NADH & NADPH & NADH & NADPH \\
\hline Crude extract & $18.25 \pm 0.21$ & $2.9 \pm 0.3$ & $80 \pm 3.2$ & $0.23 \pm 0.01$ & $0.036 \pm 0.059$ & 1.00 & 1.00 & 100 & 100 \\
\hline Heating at $50^{\circ} \mathrm{C}$ & $21.7 \pm 0.8$ & $3.4 \pm 0.1$ & $69 \pm 2.3$ & $0.31 \pm 0.02$ & $0.05 \pm 0.03$ & $1.35 \pm 0.07$ & $1.39 \pm 0.06$ & $119 \pm 6.2$ & $117 \pm 6.4$ \\
\hline $\begin{array}{l}\text { Salt precipitation } \\
\left(\mathrm{NH}_{4}\right)_{2} \mathrm{SO}_{4}\end{array}$ & $11.1 \pm 0.8$ & $1.76 \pm 0.12$ & $15.9 \pm 1.0$ & $0.70 \pm 0.43$ & $0.11 \pm 0.02$ & $3.04 \pm 0.17$ & $3.06 \pm 0.14$ & $60.8 \pm 3.1$ & $60.7 \pm 2.9$ \\
\hline HPLC & $8.87 \pm 0.52$ & $1.41 \pm 0.09$ & $0.172 \pm 0.01$ & $51.65 \pm 2.84$ & $8.2 \pm 0.37$ & $225 \pm 12$ & $228 \pm 14$ & $48.6 \pm 3.0$ & $48.6 \pm 4.2$ \\
\hline
\end{tabular}

Table 3 The apparent $K_{\mathrm{m}}$ values of TsGDH1

\begin{tabular}{llll}
\hline Substrate & \multicolumn{2}{l}{$K_{\mathrm{m}}$ values $[\mathrm{M}]$} & \\
\cline { 2 - 4 } & $\mathrm{NADH}$ & $\mathrm{NADPH}$ & $\mathrm{NAD}^{+}$ \\
\hline $\mathrm{NH}_{4}{ }^{+}$ & $1.2 \times 10^{-4} \pm 2.1 \times 10^{-6}$ & $4.8 \times 10^{-5} \pm 2 \times 10^{-4}$ & - \\
2-Oksoglutarate & $6 \times 10^{-3} \pm 6.6 \times 10^{-5}$ & $3.1 \times 10^{-3} \pm 2.6 \times 10^{-4}$ & - \\
L-Glutamic acid & - & - & $-9 \times 10^{-4} \pm 0.9 \times 10^{-5}$ \\
$\mathrm{NADH}$ & $5.9 \times 10^{-8} \pm 7.8 \times 10^{-9}$ & $3.3 \times 10^{-7} \pm 0.6 \times 10^{-7}$ & - \\
$\mathrm{NADPH}$ & - & - & $3.97 \times 10^{-8} \pm 1.4 \times 10^{-9}$ \\
NAD $^{+}$ & - & - &
\end{tabular}

The numbers represent average \pm SD resulting from the Lineveawer-Burk calculations of at least three enzyme preparations, measured in duplicates at five concentration points for a given compound

so-called cathode form usually assigned with a catabolic activity (Miyashita and Good 2008; Purnell et al. 2005), may indicate that the enzyme catalyzes the reaction of oxidative deamination of the L-glutamate freed from the proteins during germination. On the other hand, the GDH is as an enzyme known for its adaptive capabilities and may carry out the anabolic reaction also under low ammonia concentration (Labboun et al. 2009; Lehman and Ratajczak 2008; Masclaux-Daubresse et al. 2002).

In summary, it can be concluded that in young triticale seedlings, there is only one isoform of the glutamate dehydrogenase, probably encoded by a single gene. It is an enzymatically active protein of low electrophoretic mobility (so-called cathode form) exhibiting a catabolic activity, which was supported by the kinetic analyses. In vitro, TsGDH1 depending on its tissue origin, acts either towards L-glutamate oxidation (in the endosperm), or L-glutamate synthesis (in the scutellum, roots, and shoots). It can be thus postulated that during the triticale seed germination the glutamate dehydrogenase may be responsible for maintaining the balance between the L-glutamate synthesis and break-up, and by that function-regulate the $\mathrm{C} / \mathrm{N}$ ratio.

Acknowledgments The authors gratefully acknowledge prof. Dr. W. Bielawski for his noble guidance, high management skills, helpful suggestions, and critical reading of the manuscript. This work was supported in part by Ministry of Science and Higher Education, Grant NN310301134.

Open Access This article is distributed under the terms of the Creative Commons Attribution Noncommercial License which permits any noncommercial use, distribution, and reproduction in any medium, provided the original author(s) and source are credited.

\section{References}

Abiko T, Wakayama M, Kawakami A, Obara M, Kisaka H, Miwa T, Aoki N, Ohsugi R (2010) Changes in nitrogen assimilation, metabolism, and growth in transgenic rice plants expressing a fungal NADP(H)-dependent glutamate dehydrogenase (gdhA). Planta 232:299-311. doi:10.1007/s00425-010-1172-3

Barash I, Sadon T, Mor H (1973) Induction of a specific isoenzyme of glutamate dehydrogenase by ammonia in oat leaves. Nat New Biol 244:150-152. doi:10.1038/newbio244150a0

Bradford MM (1976) A rapid and sensitive method for the quantification of microgram quantities of protein utilizing the principle of protein-dye binding. Anal Biochem 72:248-254. doi:10.1016/0003-2697(76)90527-3

Chomczynski P, Sacchi N (1987) Single-step method of RNA isolation by acid guanidinum thiocyanate-phenol-chloroform extraction. Anal Biochem 162:156-159

Consalvi V, Chiaraluce R, Politi L, Vaccaro R, De Rosa M, Scandurra R (1991) Extremely thermostable glutamate dehydrogenase from 
the hyperthermophilic archaebacterium Pyrococcus furiosus. Eur J Biochem 202:1189-1196. doi:10.1111/j.1432-1033.1991. tb16489.x

Dubois F, Tercé-Laforgue T, Gonzalez-Moro MB, Estavillo MB, Sangwan R, Gallais A, Hirel B (2003) Glutamate dehydrogenase in plants; is there a new story for an old enzyme? Plant Physiol Biochem 41:565-576. doi:10.1104/pp.104.047548

Fontaine J-X, Saladino F, Agrimonti C, Bedu M, Terce-Laforgue T, Tetu T, Hirel B, Restivo FM, Dubois F (2006) Control of the synthesis and subcellular targeting of the two GDH genes products in leaves and stems of Nicotiana plumbaginifolia and Arabidopsis thaliana. Plant Cell Physiol 47:410-418. doi: 10.1093/pcp/pcj008

Glevarec G, Bouton S, Jaspard E, Riou M-T, Cliguet B, Suzuki A, Limami AM (2004) Respective roles of the glutamine synthetase/glutamate synthase cycle and glutamate dehydrogenase in ammonium and amino acid metabolism during germination and post-germinative growth in the model legume Medicago truncatula. Planta 219:286-297. doi:10.1007/s00425-004-1214-9

Hodges M (2002) Enzyme redundancy and the importance of 2-oxoglutarate in plant ammonium assimilation. J Exp Bot 53:905-916. doi:10.1093/jexbot/53.370.905

Hudson RC, Daniel RM (1993) L-Glutamate dehydrogenase: distribution, properties and mechanism. Comp Biochem Physiol 106:767-792

Kwinta J, Bartoszewicz K, Bielawski W (2001) Purification and characteristics of glutamate dehydrogenase (GDH) from triticale roots. Acta Physiol Plant 23:399-405. doi:10.1007/s11738-0020052-2

Labboun S, Terce-Laforgue T, Roscher A, Bedu M, Restivo FM, Velanis CN, Skopelitis DS, Moshou PN, Roubelakis-Angelakis KA, Suzuki A, Hirel B (2009) Resolving the role of plant glutamate dehydrogenase I. In vivo real time nuclear magnetic resonance spectroscopy experiments. Plant Cell Physiol 50:1761-1773. doi:10.1093/pcp/pcp118

Laemmli UK (1970) Cleavage of structural proteins during the assembly of the head of bacteriophage T4. Nature 227:680-685. doi: $10.1038 / 227680 \mathrm{a} 0$

Lehman T, Ratajczak L (2008) The pivotal role of glutamate dehydrogenase $(\mathrm{GDH})$ in the mobilization of $\mathrm{N}$ and $\mathrm{C}$ from storage material to asparagine in germinating seeds of yellow lupine. J Plant Physiol 165:149-158. doi:10.1016/j.jplph.2006. 12.010

Lehman T, Polcyn W, Ratajczak L (1990) Glutamate dehydrogenase isoenzymes in yellow lupine root nodules III. Affinity for ammonia. Acta Physiol Plant 12:259-263. doi:10.1111/j.13993054.2009.01294.x

Leon E, de la Haba P, Maldonado JM (1990) Changes in the levels of the enzymes involved in ammonia assimilation during the development of Phaseolus vulgaris seedlings. Effects of exogenous ammonia. Physiol Plant 80:20-26. doi:10.1111/j.13993054.1990.tb04369.x

Lineweaver M, Burk DJ (1934) The determination of enzyme dissociation constants. J Am Chem Soc 56:658-666

Loulakakis KA, Roubelakis-Angelakis KA (1991) Plant NADHglutamate dehydrogenase consist of two subunit polypeptides and their participation in the seven isoenzymes occurs in an ordered ratio. Plant Physiol 97:104-111

Loulakakis KA, Roubelakis-Angelakis KA (1992) Ammonium induced increase in $\mathrm{NAD}(\mathrm{H})$-glutamate dehydrogenase activity is caused by de novo synthesis of the $\alpha$-subunit. Planta 187:322-327

Loulakakis KA, Roubelakis-Angelakis KA (1996) The seven $\mathrm{NAD}(\mathrm{H})$-glutamate dehydrogenase isoenzymes exhibit similar anabolic and catabolic activities. Physiol Plant 96:29-35. doi: 10.1111/j.1399-3054.1996.tb00179.x

Masclaux-Daubresse C, Valadier M-H, Carrayol E, Reisdorf-Cren M, Hirel B (2002) Diurnal changes in the expression of glutamate dehydrogenase and nitrate reductase are involved in the $\mathrm{C} / \mathrm{N}$ balance of tobacco source leaves. Plant Cell Environ 25:14511462. doi:10.1046/j.1365-3040.2002.00925.x

Masclaux-Daubresse C, Reisdorf-Cren M, MPageau K, Lelandais M, Grandjean O, Kronenberger J, Valadier M-H, Feraud M, Jouglet T, Suzuki A (2006) Glutamine synthetase/glutamate synthase pathway and glutamate dehydrogenase play distinct roles for sink/source nitrogen cycle in tobacco (Nicotiana tabacum L.). Plant Physiol 140:444-456. doi:10.1104/pp.105.071910

Melo-Oliveira R, Oliveira IC, Coruzzi GM (1996) Arabidopsis mutant analysis and gene regulation define a non-redundant role for glutamate dehydrogenase in nitrogen assimilation. Pro Nation Acad Sci USA 93:4718-4723

Miyashita Y, Good AG (2008) NAD(H)-dependent glutamate dehydrogenase is essential for the survival of Arabidopsis thaliana during dark-induced carbon starvation. J Exp Bot 59:667-681. doi:10.1093/jxb/erm340

Purnell MP, Botella JR (2007) Tobacco isoenzyme 1 of NAD(H)dependent glutamate dehydrogenase catabolizes glutamate in vivo. Plant Physiol 143:530-539. doi:10.1104/pp.106.091330

Purnell MP, Stewart GR, Botella JR (1997) Cloning and characterization of a glutamate dehydrogenase cDNA from tomato (Lycopersicum esculentum L.). Gene 186:249-254. doi:10.1016/ S0378-1119(96)00716-0

Purnell MP, Skopelitis DS, Roubelakis-Angelakis K, Botella JR (2005) Modulation of higher-plant $\mathrm{NAD}(\mathrm{H})$ dependent glutamate dehydrogenase activity in transgenic tobacco via alteration of beta subunit level. Planta 222:167-180. doi:10.1007/s00425$005-1510-z$

Qiu X, Xie W, Lian X, Zhang Q (2009) Molecular analyses of the rice glutamate dehydrogenase gene family and their response to nitrogen and phosphorous deprivation. Plant Cell Rep 28:11151126. doi:10.1007/s00299-009-0709-z

Restivo FM (2004) Molecular cloning of glutamate dehydrogenase genes of Nicotiana plumbagifolia: structure analysis and regulation of their expression by physiological and stress conditions. Plant Sci 166:971-982. doi:10.1016/j.plantsci.2003.12.011

Robinson SA, Stewart GR, Phillips R (1992) Regulation of glutamate dehydrogenase activity in relation to carbon limitation and protein catabolism in carrot cell suspension cultures. Plant Physiol 98:1190-1195

Sakakibara H, Fuji K, Sugiyama T (1995) Isolation and characterization of a cDNA that encodes maize glutamate dehydrogenase. Plant Cell Physiol 36:789-797

Skopelitis DS, Paranychianakis NV, Kouvarakis A, Spyros A, Stephanou EG, Roubelakis-Angelakis KA (2007) The isoenzyme 7 of tobacco $\mathrm{NAD}(\mathrm{H})$-dependent glutamate dehydrogenase exhibits high deaminating and low aminating activities in vivo. Plant Physiol 145:1726-1734. doi:10.1104/pp.107.107813

Thompson JD, Higgins DG, Gibson TJ (1994) Improving the sensitivity of progressive multiple sequence alignment through sequence weighting, position-specific gap penalties and weight matrix choice. Nucleic Acids Res 22:4673-4680. doi:10.1093/ nar/22.22.4673

Turano FJ, Dashner R, Upadhyaya A, Caldwell CR (1996) Purification of mitochondrial glutamate dehydrogenase from dark-grown soybean seedling. Plant Physiol 112:1357-1364

Turano FJ, Thakkar SS, Fang T, Weiseman T (1997) Characterization and expression of $\mathrm{NAD}(\mathrm{H})$-dependent glutamate dehydrogenase genes in Arabidopsis. Plant Physiol 113:1329-1341 